\begin{tabular}{|c|c|}
\hline \multicolumn{2}{|c|}{ Publisherlnfo } \\
\hline PublisherName & : BioMed Central \\
\hline PublisherLocation & London \\
\hline Publisherl mprintName & BioMed Central \\
\hline
\end{tabular}

\title{
Reactive oxygen species (ROS) generated in vitro decreases human small intestinal muscle contractions and inhibitory neuromuscular transmission
}

\begin{tabular}{|c|c|c|}
\hline \multicolumn{3}{|c|}{ Articlelnfo } \\
\hline ArticlelD & : 1372 & \\
\hline ArticleDOI & : 10.1186/cc1331 & \\
\hline ArticleCitationID & : P267 & \\
\hline ArticleSequenceNumber & $: 260$ & \\
\hline ArticleCategory & : Meeting abstract & \\
\hline ArticleFirstPage & $: 1$ & \\
\hline ArticleLastPage & $: 2$ & \\
\hline \multirow[t]{3}{*}{ ArticleHistory } & : RegistrationDate & 2001-1-15 \\
\hline & Received & 2001-1-15 \\
\hline & OnlineDate & $2001-3-2$ \\
\hline ArticleCopyright & : The Author(s)2001 & \\
\hline ArticleGrants & : & \\
\hline ArticleContext & : 1305455S1S1 & \\
\hline
\end{tabular}

NT Schwarz, Aff1

BM Engel, ${ }^{\text {Aff1 }}$

J C Kalff, Aff1

WH Schraut, Aff1

AJ Bauer, ${ }^{A f f 1}$

Aff1 Department of Surgery and Department of Medicine, University of Pittsburgh, Pittsburgh, PA 15261, USA 


\section{Background \& Aims}

A common component to the transmural intestinal inflammation caused by IBD, hemorrhagic shock, ischemia/reperfusion injury, sepsis and intestinal manipulation is the recruitment of leukocytes into the gut muscularis, which is accompanied by ileus. Phagocytes are potent producers of ROS, but the direct effect of radicals on human intestinal muscle is undetermined. The purpose of this study was to determine the mechanisms of action by which superoxide alters human intestinal muscle contractility.

\section{Methods}

Human intestinal waste tissue was obtained and used for in vitro mechanical, intracellular electrical and electrical field stimulated neuromuscular transmission recording experiments $(P<0.05, n=3)$. Dispersed, isolated smooth muscle cells loaded with INDO-1 were used to determine ratiometric changes in cytosolic calcium concentrations. Superoxide radicals were generated in vitro with xanthine oxidase (XO) $(20 \mathrm{mU} / \mathrm{ml})$ + hypoxanthine $(100 \mu \mathrm{M})$ or by pyrogallol $(100 \mu \mathrm{M})$.

\section{Results}

Phasic in vitro human intestinal muscle contractions were $77.2 \%$ and $71 \%$ significantly inhibited by superoxides generated by xanthine oxidase $(647.5 \pm 191.24$ vs $148.2 \pm 46.54 \mathrm{~g} / \mathrm{s})$ and pyrogallol $(886.5 \pm$ 93.48 vs $264 \pm 16.32 \mathrm{~g} / \mathrm{s}$ ). This decrease in contractility appeared to be due to resting membrane hyperpolarization and alterations in cytosolic calcium utilization. Intracellular electrical recordings showed that XO generated superoxides caused a significant $4.5 \mathrm{mV}$ hyperpolarization in the resting membrane potential ( $-52 \pm 1.3$ vs $-56.5 \pm 0.9 \mathrm{mV}$ ) and a decrease in membrane oscillation amplitudes. Additionally, pyrogallol decreased isolated myocyte cytosolic calcium utilization by $54 \%$ in muscle cells stimulated with bethanechol $(10 \mu \mathrm{M})(\mathrm{KRB}: 442.7 \pm 98.90$ vs $203.1 \pm 5.83 \mathrm{nM}, n=3)$. Inhibitory neurogenic activity was also diminished by $\mathrm{XO}$, as single pulse EFS caused a $23 \pm 2.3 \mathrm{mV}$ hyperplarization in membrane potential in $\mathrm{KRB}$, but only a $13 \pm 3.4 \mathrm{mV}$ hyperpolarization in $\mathrm{XO}$.

\section{Conclusion}

We hypothesize that ROS generated by endogenous XO or phagocyte NADPH-oxidase within the inflamed muscularis plays a common role in numerous transmural inflammatory disease states. Furthermore, ROS appear to cause intestinal ileus via multiple mechanisms, which alter both muscle and enteric neural functions. 
